\title{
Jędrzej Kitowicz a konfederacja barska
}

Wiesław Majewski 
nAPTS Seria VII 2001

\section{Wiesław Majewski}

\section{Jędrzej Kitowicz a konfederacja barska}

\section{Oblicze Baru}

$\mathrm{W}$ literaturze historycznej III Rzeczypospolitej panuje w zasadzie obraz konfederacji barskiej $z$ doby PRL-u ${ }^{1}$. Pisząc więc o Kitowiczu, uczestniku tego ruchu, i o jego pogląadach, wypada odkłamać oblicze tego związku.

Zwykło się wywodzić konfederację barską z konfederacji radomskiej. Rzeczywiście znaczna część przywódców późniejszej konfederacji należała do wcześniejszej ${ }^{2}$. Wywodzenie jednak Baru z Radomia ma podobny sens, jak wywodzenie stronnictwa patriotycznego Sejmu Czteroletniego z opozycji magnackiej z roku 1788, mimo że wielu jego przywódców należało do tej drugiej, w której znaleźli się też przyszli przywódcy Targowicy, jak Ksawery Branicki i Szczęsny Potocki. Podobnie nie wszyscy przywódcy radomian znaleźli się w konfederacji barskiej. Część z nich, jak prymas Gabriel Podoski czy Adam Poniński, zasiliła szeregi stronnictwa rosyjskiego.

„Familia” Czartoryskich, chcąc przejąć władzę w Rzeczypospolitej, wprowadziła do niej wojska Katarzyny II w roku 1763. Spowodowała tym uzależnienie państwa od carycy. Dzięki tej władczyni Stanisław August Poniatowski został królem.

W roku 1767 Rosjanie doszli do wniosku, że „familia”, a także król zaczynają okazywać zbyt dużo samodzielności. Postanowili więc ich postraszyć, przeciwstawiając im drugą ekipę, złożoną z przywódców pozostającego w opozycji stronnictwa saskiego. Rosjanie doprowadzili do zawiązania konfederacji radomskiej, mamiąc przekazaniem władzy w ręce przywódców stronnictwa saskiego, a nawet detronizacją króla. Spora część szlachty mogła się łudzić, że przejście władzy w ręce opozycji, która podejmowała w roku 1764 walkę z Rosją, doprowadzi do przywrócenia suwe-

\footnotetext{
1 Zob. W. Majcwski, Konfederacja barska, w: Zestańcy w tworzeniu państwowości polskiej (III Sympozjum popularno-naukowe dla nauczycieli historii szkót podstawouych i średnich na temat: Znaczenie edukacyjne losów polskich zesłańców syberyjskich na tle historii najnowszej), red. M. Morawicc, Warszawa 1998, s. 46-47 (dalcj: M KB).

2 Tckst tcgo podrozdziału jest w zasadzic oparty na cytowanym już artykulc, $M K B$, s. 49-58. Wyjątkowo daje tu szczególowe przypisy.
} 
renności Rzeczypospolitej. Było to niewątpliwie złudzenie co do części przywódców stronnictwa saskiego, ale nie co do wszystkich. Bagnety rosyjskie, pod którymi utworzono Generalność konfederacji radomskiej, wymusiły na niej wiązanie się przy Stanisławie Auguście. Ten bowiem znowu teraz w pełni uległ carycy. Zmuszono konfederację do formalnego uznania protektoratu Rosji.

Teraz rozeszły się drogi radomian. $\mathrm{Ci}$, którzy weszli do tej konfederacji w celu przywrócenia suwerenności, zawiązali spisek, z którego wyrósł $\mathrm{Bar}$. Ci, których zadowoliło przejęcie części władzy przez przywódców stronnictwa saskiego, a mieli też nadzieję, że wierną służbą Rosji doprowadzą do powrotu dynastii saskiej, weszli do ugrupowania prorosyjskiego.

Właściwym przodkiem Baru nie jest Radom, ale konfederacje walczące $\mathrm{z}$ bronią $\mathrm{w}$ ręku w obronie suwerenności Rzeczypospolitej: tarnogrodzka (1715-1717) i dzikowska (1734-1736). Jest to nawet uchwytne personalnie. Jednym z dwóch twórców konfederacji barskiej był Józef Pułaski, uczestnik konfederacji dzikowskiej. W jej trakcie zaprzyjaźnił się z jednym z przywódców Dzikowa, regimentarzem Kazimierzem Rudzińskim, wcześniej uczestnikiem konfederacji tarnogrodzkiej. Podzielali oni poglądy polityczne, przyjaźń ich przetrwała do śmierci Rudzińskiego w roku 1759.

W konfederacji barskiej występowały różne zwalczające się wzajemnie ugrupowania polityczne, tak jak to miało miejsce w każdym powstaniu narodowym, by wspomnieć tylko białych i czerwonych w roku 1863.

Było tu skrajne ugrupowanie saskie, dążące bezwzględnie do detronizacji Stanisława Augusta. Do jego przywódców należeli między innymi: Teodor Wessel, ks. Karol Radziwiłł „Panie Kochanku”. Było umiarkowane ugrupowanie saskie biskupa Adama Krasińskiego, ze względów taktycznych nie dopuszczające do ogłoszenia aktu o bezkrólewiu; dla niego powrót dynastii saskiej nie był bezwzględnym dogmatem. Dopuszczało ono nawet porozumienie $z$,familią”. Było ugrupowanie centralne z Michałem Pacem na czele, oscylujące między Wesslem a Krasińskim. Byli przywódcy konfederaccy uznający królewskość Stanisława Augusta, jak Józef Pułaski i Józef Zaremba, a nawet wręcz liczni zwolennicy „familii”: jeden z jej przywódców, hetman wielki litewski Michał Kazimierz Ogiński, wystąpił w roku 1771 zbrojnie po stronie konfederacji.

Tym, co łączyło niemal wszystkich barzan różnych ugrupowań, była niepodległość Polski. O nią cały czas toczyła się wojna. Akt zawiązania konfederacji barskiej z 29 marca 1768 roku kładl nacisk na sprawę niepodległości. Sam jego początek mówił o zawiązaniu się ruchu „na ratunek ojczyzny, wiary, wolności, praw i swobód narodowych". Ojczyznę wymieniono tu pierwszą przed wolnościami, a nawet przed wiarą ${ }^{3}$.

Walczono cały czas z Rosjanami, elementy wojny domowej występowały jedynie sporadycznie. Od jesieni 1768 roku walki przeciw rodakom zdarzały się rzadko. Dopiero po ogłoszeniu aktu bezkrólewia, od maja 1771 roku parę tysięcy wojsk królewskich stale wspierało Rosjan. I wówczas jednak siły te stanowiły jedynie nieznaczny dodatek do armii Katarzyny II.

Mocno uproszczone jest widzenie w przywódcach Baru jedynie „ciemnych Sarmatów”. Stosunek konfederacji barskiej do reform to sprawa mocno skomplikowana. Z pewnością akt jej zawiązania kasował reformy z lat 1764-1766, ale trzeba pamiętać, że spora część z nich przekazywała władzę z rąk dygnitarzy opozycyjnych w ręce „familii”, jak wymienione odrębnie w tym akcie ustawy ograniczające władzę hetmańską ${ }^{4}$. Trzeba jednak też pamiętać, że uprzednio Adam

\footnotetext{
${ }^{3}$ Zob. Konfederacja barska. Wybór tekstów, opr. W. Konopczyński, Kraków 1928, s. 5 (dalej: KB), zob. też: M KB, s. 55.

${ }^{4} K B$, s. 5, 9, zob. tez: $M K B$, s. 57-58.
} 
Krasiński chwalił dzieło Stanisława Konarskiego O skutecznym rad sposobie występujące przeciw liberum veto. Już na przełomie lat 1768-1769 niektórzy przywódcy Baru zaczynają myśleć o reformach i nurt ten nie zanika do końca konfederacji.

Wolnomularstwo to czołowa organizacja ludzi oświecenia. Jedną z podstawowych jej zasad była tolerancja religijna. Wśród członków Generalności w Preszowie - centralnej władzy konfederacji — było tylu masonów, że utworzono dla nich w roku 1770 lożę „Cnotliwy Wędrowiec”. Konfederacja barska zwalczała równouprawnienie dysydentów-protestantów wprowadzone na sejmie 1767-1768 roku, co miało zresztą charakter bardziej polityczny niż religijny: Katarzynie II chodziło o utworzenie z ludzi tych wyznań stronnictwa prorosyjskiego. Władze konfederackie nie występowały natomiast przeciw równouprawnieniu prawosławnych. Przywódcy Baru nie chcieli zrażać Ukraińców-żołnierzy i oficerów wojsk nadwornych prawosławnych lub sympatyzujących z prawosławiem. Ta polityka działała skutecznie aż do wybuchu w czerwcu 1768 roku koliszczyzny, niewątpliwie z inspiracji rosyjskiej (najpewniej Piotra Rumiancewa, przewodniczącego Kolegium Małorosyjskiego). Ukraińcy stanowiący co najmniej połowę, jeśli nie większość żołnierzy barskich w okresie podolsko-bracławskim (luty-czerwiec 1768 r.), bili się, jak na żołnierzy konfederackich, całkiem dobrze. Część z nich również i później służyła wiernie w szeregach barskich ${ }^{5}$.

Katolicki charakter konfederacji barskiej najsilniej występował w podolsko-bracławskim okresie ruchu (pierwsza połowa r. 1768), głównie dzięki księdzu Markowi Jandołowiczowi. Konfederacja jednak do końca zachowała swoje oblicze patriotyczno-religijne, na co wskazują liczne wiersze z późniejszych okresów działalności tego ruchu.

Nadal egzystuje mit historiograficzny, że konfederacja barska była kierowana przez magnatów. W rzeczywistości w ruchu tym dochodzi właśnie do emancypacji szlachty spod wpływów magnaterii. Radziwiłła „Panie Kochanku” i magnatów wielkopolskich to właśni klienci ciągną do konfederacji. O obliczu ruchu decydują marszałkowie i regimentarze działający w kraju, a należący do średniej czy nawet ubogiej szlachty. Nie należą do magnaterii: Kazimierz i Franciszek Pułascy, Józef Zaremba, Michał Walewski, Józef Miączyński, Józef Bierzyński, Ignacy Malczewski i wielu, wielu innych. W ogóle nie był szlachcicem Kozak Józef Sawa-Caliński, marszałek wyszogrodzki. Kiedy Józef Zaremba, regimentarz wielkopolski odmówił w roku 1770 ogłoszenia aktu bezkrólewia, Generalność nie miała możliwości go do tego zmusić. Niewątpliwie to dzięki przykładowi emancypacji szlachty konfederacji barskiej tak szybko dochodzi do emancypacji posłów Sejmu Czteroletniego, w większości klientów magnackich, spod wpływu swoich patronów.

Niepodległościowy charakter konfederacji barskiej sprawia, że przyłączają się do niej mieszczanie wielkopolscy i krakowscy, a sympatyzują z nią warszawiacy. Pewna liczba mieszczan wielkopolskich otrzymała w konfederacji stopnie oficerskie, a Antoni Morawski został nawet pułkownikiem. Ochotniczo zaciągają się do konfederacji nawet chłopi, szczególnie górale, Kurpie i Żmudzini.

5 Zob. W. Majewski, Bar poustaniem narodowym. Konfederacja barska na Ukrainie i Białorusi, w: Ostatnie lata I Rzeczypospolitej, red. T. Rawski, Łowicz 1996, s. 53-68; M KB, s. 68. 
Konfederaci barscy znaleźli się w szeregach stronnictwa patriotycznego w dobie Sejmu Czteroletniego nawet wśród jego przywódców, jak biskup Krasiński, a później, czasem nawet w stopniach generalskich (jak Józef Zajączek czy Antoni Madaliński), w wojsku powstania 1794 roku. Jako major jazdy służył w nim i Antoni Morawski. Niewątpliwie trafiali się wśród nich i targowiczanie, jak hetman Szymon Kossakowski. Ale to jedyna postać z takim rodowodem politycznym wśród czołowych przywódców tego ugrupowania. Natomiast jest między nimi pogromca barzan, hetman Ksawery Branicki.

Kitowicz aprobuje nieogłoszenie aktu bezkrólewia przez Zarembę, ale w przeciwieństwie do swego dowódcy odnosi się krytycznie do króla. Jeśli chodzi o poglądy polityczne, trzeba więc autora Pamiętników umieścić gdzieś międ zy regimentarzem wielkopolskim a Adamem Krasińskim.

\section{Kitowicz w wojsku konfederackim}

Jędrzej Kitowicz urodził się 1 grudnia 1728 roku, najprawdopodobniej w Warszawie, w niezamożnej rodzinie szlacheckiej. Tu w każdym razie mieszkał w styczniu 1734 roku w domu rodziców i tu uczęszczał do szkoły średniej, tak zwanej publicznej, raczej jezuickiej niż pijarskiej; zakończył ją na retoryce. Prawdopodobnie od roku 1744 służył u biskupa poznańskiego Teodora Czartoryskiego. Zapewne w roku 1747 lub 1748 przeszedł do dragonii nadwornej księcia Janusza Sanguszki ordynata ostrogskiego ${ }^{6}$. W roku 1751 służył u księdza Michała Lipskiego, od roku 1752 opata komendatoryjnego w Lubiniu. Był jego sekretarzem aż do przełomu lat 1768-1769.

Co skłoniło Kitowicza do wstąpienia do wojska konfederackiego? Brak podstaw, aby sądzić, że stało się to pod wpływem jego zwierzchnika ks. Michała Lipskiego (jak uważa Danuta Maniewska), bo nie ma jakichkolwiek danych, że ów ksiądz był zwolennikiem konfederacji, przeciwnie, prawdopodobnie był on zwolennikiem Stanisława Augusta (w roku 1767 dostał order św. Stanisława, a w roku 1773 został referendarzem koronnym) ${ }^{7}$.

Surowo Kitowicz oceniał tych, którzy zaciągnęli się do oddziałów konfederackich Malczewskiego ze względów materialnych:

Płaca dobra, (...) rozpusta i debosz, rozkazywanie absolutne i panowanie nad obywatelami, uniżoność od panów największych (...) nęciła na potęgę do siebie [do wojska konfederackiego - W. M.] wszystkich golców, służalców dworskich, mieszczanków i wieśniaków krnąbrnych albo pracy nie lubiących. (...) Za jedną lub dwie godziny strachu w potyczce i ucieczce wytrzymanego dosyć było nadgrody bujać wygodnie po kraju w ozdobie obrońcy wiary i wolności, i do tego być dobrze płatnym ${ }^{8}$.

\footnotetext{
${ }^{6}$ Informacje o szlachectwie Kitowicza i o jego dzicciństwie w Warszawic zostały oparte na moim artykulc Wokót życia i poglqdów Jędrzeja Kitowicza, rps (dalcj: M WJK). Uzasadnienic służby u J. Sanguszki zob. niżcj.

7 Zob. D. Maniewska, Zagadki życia i twórczości Jędrzeja Kitowicza w świetle listów z Biblioteki Polskiej w Paryżu i dokumentów archiwalnych, „Archiwum Literackie”, t. 6: Miscellanea staropolskie, t. 1, Wrocław 1962, s. 349; M WJK.

${ }^{8}$ J. Kitowicz, Pamiętniki czyli historia Polski, opr. i wst. P. Matuszewska, koment. Z. Lewinówna, Warszawa 1971, s. 205 (dalej: $P$ ).
} 
Wyklucza to zarówno owe wspomniane motywy, jak i przypuszczenie Władysława Konopczyńskiego, że w konfederacji Kitowicz szukał „awansu społecznego”.

Maniewska w dalszych rozważaniach wysuwa przypuszczenie, że do wstąpienia do wojska konfederackiego mogły skłonić Kitowicza „znajomości z kaliskimi organizatorami ruchu”, z Antonim Sieraszewskim (właściwie Sieroszewskim), Wojciechem Kiedrzyńskim, Ignacym Malczewskim ${ }^{10}$. Nic w Pamiętnikach bynajmniej nie wskazuje, by byli to znajomi Kitowicza. Określenie „niejaki Kiedrzyński” bez podania imienia wręcz temu przeczy, jeśli chodzi o tę osobę. Wątpliwe są też w ogóle ściślejsze związki Kitowicza z Kaliskiem. Maniewska pisze o powiązaniu jego chlebodawcy Lipskiego $z$ tą ziemią ${ }^{11}$. Sądzę, że od roku 1752, czyli od uzyskania przez tegoż duchownego opactwa w Lubiniu (7 km na wschód od Krzywinia, $12 \mathrm{~km}$ na północny zachód od Gostynia) w ówczesnym powiecie kościańskim, właśnie ta miejscowość stała się główną siedzibą Lipskiego, w pobliżu niej bowiem leżała większość jego majątków, podczas gdy w Choczu (nad Prosną na północ od Pleszewa) w powiecie kaliskim miał tylko probostwo.

W tej sytuacji jako jedyny motyw wstąpienia Kitowicza do wojska konfederackiego pozostaje kierowanie się patriotyzmem. Uczucie to wielokrotnie przebija w Pamiętnikach. Tak pisze o tym Henryk Barycz:

Kitowicz to pierwszy w historiografii piewca niepodległości Polski, historyk i ideolog czynu zbrojnego w okresie zaczynającego się ujarzmienia Polski.

Przez Pamiętniki przewija się „nić uwielbienia i zrozumienia potrzeby czynu zbrojnego w obronie niepodległości Polski”. Nawet w opisie „kampanii 1792 roku potrafi wydobyć momenty męstwa i poświęcenia dla Ojczyzny". "Jakąż zwłaszcza dumą napawa go «wspaniałe dzieło» obrony Warszawy w 1794 roku”. „Nie ma też słów oburzenia dla tych, którzy (...) przechodzili pod obce sztandary" w roku $1792^{12}$.

Biorąc pod uwagę zaawansowany wiek Kitowicza (1 grudnia 1768 roku ukończył 40 lat), jak i uzyskanie pewnej stabilizacji życiowej (sekretariat u Lipskiego i wójtostwo w Wieszkowie), nie byłoby mu łatwo zamieniać to na niebezpieczeństwa i trudy życia wojskowego, zwłaszcza jeśli nie miało się z nim poprzednio do czynienia. Ułatwiłby tę decyzję fakt uprzedniej służby Kitowicza w wojsku. Uważam, że miało to rzeczywiście miejsce. Książę Janusz Sanguszko, ordynat ostrogski „przeważnie rezydował” w Dubnie ${ }^{13}$. O tamtejszej milicji nadwornej Kitowicz miał bardzo szczegółowe informacje, wskazujące na autopsję ${ }^{14}$. Jest w Pamiętnikach obszerna relacja o korona-

\footnotetext{
9 W. Konopczyński, Szkoda, że to nie powieš́, „Tygodnik Powszechny” 1951, nr 51/52, s. 6 (dalej: Szkoda).

10 Zob. D. Maniewska, op. cit., s. 349.

11 Ibidem, s. 344.

12 H. Barycz, Jędrzej Kitowicz — pamiętnikarz, powieściopisarz, historyk?, w: idem, Szlakami dziejopisarstua staropolskiego. Studia nad historiografiq w. XVI-XVIII, Wrocław 1981, s. 277-279.

13 Zob. R. Marcinck, Sanguszko Janusz, w: Polski slounik biograficzny, t. 34, Wrocław 1992, s. 497.

${ }_{14}$ Zob. J. Kitowicz, Opis obyczajów za panowania Atugusta III, wst. M. Dernałowicz, Warszawa 1985, s. 203 (dalcj w tekścic: $O I I I)$; tekst identyczny z wydaniem z roku 1999. Wydanie Opisu..., opr. R. Pollak. Wrocław 1951 (dalej w tekście: $O I$ ).
} 
cji obrazu Matki Boskiej w roku 1748 w Łucku, odległym od Dubna o 60 km (P 52). Wskazywałoby to, że Kitowicz był przy tej uroczystości ${ }^{15}$. Pamiętniki szeroko opisują trybunał koronny w roku 1750, którego marszałkiem był Janusz Sanguszko, a raczej jest to informacja o ordynacie na tym trybunale. Do niej dochodzi przedstawienie sylwetki moralnej księcia ( $P$ 60-65, 70-72). Są dość liczne wzmianki o nim w Opisie obyczajów (O III 125, 173, 189, 190, 203, 209, 215, 237).

Jeśli chodzi o Dubno, poza szerokim ujęciem postaci samego księcia Kitowicz najwięcej napisał o tamtejszej nadwornej milicji, o piechocie i dragonii. „Dragonia dubieńska noszona była [umundurowana - W. M.] porządnie jako zawsze na oczach księcia ordynata zostająca”. Natomiast piechota, „chłopi wyprawni ze wsiów”, „chodziła w prostych butach chłopskich z podkówkami i odarto”, „zimą tęgą stawali na warcie i w kożuchach, osobliwie na pocztach od oka publicznego odległych" (O III 203). Wygląda to wyraźnie na autopsję. Mało prawdopodobne, by o tych drobnych, charakterystycznych szczegółach dowiedział się od kogoś. Co więcej, mamy tu raczej spojrzenie od wewnątrz niż z zewnątrz: skoro tak było „na pocztach od oka publicznego odległych", mało prawdopodobne, by wiedział o tym ktoś niebędący domownikiem. Zapewne więc Kitowicz był oficerem milicji nadwornej Sanguszki. Obdarta piechota nie miała szans, by znaleźć się na trybunale (1750) obszernie opisanym przez Kitowicza, natomiast porządnie umundurowana dragonia - tak. Wskazywałoby to, że Kitowicz był oficerem tej ostatniej.

W Wielkopolsce brakowało fachowych żołnierzy wojsk nadwornych, było tu ich najprawdopodobniej stosunkowo najmniej w Rzeczypospolitej. W tej sytuacji Kitowicz mający za sobąjakieś doświadczenie wojskowe jako oficer dragonii Sanguszki, jako patriota mógł uważać za swój obowiązek wziąć udział w konfederacji, mimo zaawansowanego wieku.

Maniewska wskazuje, że na decyzję wstąpienia Kitowicza do wojska konfederackiego mogło oddziałać zetknięcie się z wybitnym dowódcą konfederackim Józefem Gogolewskim. Ten pokwitował 21 października 1768 roku jakąś dostawę z klasztoru lubińskiego ${ }^{16}$. Niewątpliwie Kitowicz odnosił się z sympatią do Gogolewskiego (P 201-205), jednak przystąpił do konfederatów zapewne w połowie stycznia 1769 roku (zob. niżej), czyli dopiero trzy miesiące po ewentualnym spotkaniu z owym dowódcą. Nie mogło to więc być bezpośrednim powodem, by zaciągnąć się do szeregów barzan, mogło jednak dać do tego pierwszy impuls. Drugim bodźcem mogły być działania Gogolewskiego znowu w pobliżu Lubinia w końcu grudnia 1768 roku: 23 grudnia był w Lesznie albo w Rydzynie (miejscowości odległe o 27 i $25 \mathrm{~km}$ w linii prostej od Lubinia), następnie odszedł do Wschowy (27 XII), 30 grudnia wrócił do Leszna, 31 grudnia był w Nietażkowie (pod Śmiglem), odległym o $25 \mathrm{~km}$ od Lubinia ${ }^{17}$.

${ }^{15}$ Zob. H. Barycz, op. cit., s. 272, zob. też: O I, s. 16.

${ }^{16}$ Zob. D. Maniewska, op. cit., s. 349.

17 Zob. W. Szczygielski, Konfederacja barska $w$ Wielkopolsce 1768-1770, Warszawa 1970, s. 104, 107, 109-110 (dalej: Sz $K B W$ ). Szczygielski na s. 104 podaje, że 24 grudnia Gogolewski pobił pod Grodziskiem rotmistrza rosyjskicgo Czapskiego. Grodzisk odległy jest od Leszna o $42 \mathrm{~km}$ w linii prostej, kłóci się więc to wyraźnic z owym spotkaniem Gogolewskiego z Malczewskim 23 grudnia w Lesznie lub Rydzynie (Sz KBW, s. 107). Zapewne wiçc data walk pod Grodziskiem jest błędna. Wiadomo o walce pod Grodziskiem 16 grudnia z księgi zmarłych parafii grodziskiej (Sz KBW, s. 104). Ta hipoteza o jednej tylko walce pod Grodziskiem 16 grudnia znalazłaby potwierdzenic w informacji, że 27 grudnia był Gogolewski we Wschowie, a więc w pobliżu Leszna (ibidem, s. 109). Wg Szczygiclskicgo 
Można by więc przypuszczać, że to wówczas, w końcu grudnia Kitowicz zaciagnął się do oddziałów Gogolewskiego. Jednakże wkrótce potem siły te stoczyły stosunkowo pomyślne walki 3 stycznia 1769 roku pod Nietażkowem, a 4 stycznia pod Kościanem i Czempiniem, o których u Kitowicza brak wzmianki. Ponieważ byłyby to pierwsze walki, w których by uczestniczył Kitowicz, ów brak byłby mocno dziwny. Jeślibyśmy przyjęli, że autor Pamiętników zaciągnął się do oddziałów Malczewskiego przebywającego 23 grudnia 1768 roku w Lesznie, to dlaczego mamy tam jedynie krótką wzmiankę o tak ważnym wydarzeniu, jak wybór tego dowódcy 29 grudnia w Koninie marszałkiem wielkopolskim ( $P$ 194)?

Szersza informacja z dziejów konfederacji wielkopolskiej w Pamiętnikach dotyczy zatargu Malczewskiego $z$ Józefem Gogolewskim, pretendującym do objęcia naczelnego dowództwa nad konfederacją wielkopolską ( $P$ 203-205). Gogolewski przybył 16 stycznia do obozu Malczewskiego do Popowa nad Wartą (na północ od miasta Warty), otoczył kwaterę marszałka i zażądał przekazania mu dowództwa nad konfederacją wielkopolską. Malczewski pozornie się na to zgodził, ale zaraz aresztował Gogolewskiego. 17 stycznia sąd polowy skazał buntownika na śmierć, po czym go rozstrzelano (Sz KBW 111-112).

Główna część opisu tej sprawy dotyczy jednak wydarzeń w kwaterze Malczewskiego, których świadkiem Kitowicz nie mógł być, nawet przebywając wówczas w Popowie. To, co mógłby ewentualnie widzieć, ujmuje bardzo krótko: „nazajutrz rano [17 I] o godzinie $8 \mathrm{w}$ ogrodzie [Gogolewskiego] rozstrzelano". Brak nawet wzmianki o sądzie (P 203-204). Najprawdopodobniej więc wiadomości o tych wydarzeniach uzyskał później, służąc w oddziałach Malczewskiego.

Pierwsza szerzej opisana przez autora Pamiętników walka konfederacji wielkopolskiej to bitwa pod Turskiem (nad Prosną, na północ od Kalisza) 2 lutego 1769 roku, stoczona przez Ignacego Skarbka Malczewskiego. Tuż po niej mamy obszerniejszą relację z bitwy pod Częstochową z 11 lutego (P206-208, Sz KBW 135-138). Zapewne więc Kitowicz uczestniczył w nich (co w odniesieniu do Częstochowy przyjmował już Konopczyński) ${ }^{18}$.

Nie ma informacji w Pamiętnikach o „wielkim popisie wojsk skonfederowanych” wielkopolskich, sieradzkich i łęczyckich w Malanowie, według Szczygielskiego odbywającym się między 24 stycznia a 2 lutego. Ta końcowa data jest błędna, skoro na 2 lub 3 lutego Szczygielski datuje walki pod Turskiem. W rzeczywistości w grę wchodzi dla tego boju tylko 2 lutego, skoro juz

(KBW, s. 104) 24 grudnia w walce pod Grodziskiem Gogolewski później „wpadł na (...) Drewitza i zmusił go do ucieczki”. Autor powołuje się tu na kilka relacji. Najblizzszy terenowo tym wydarzeniom był Stanisław A. Morzkowski, marszałek wieluński. Ten w liście z 13 stycznia 1769 roku informuje jedynie o walce z Czapskim. Informacja, że „Drewicz miał iść z resztą ludzi [swojej grupy] do Poznania”, nie wiąże tego bynajmnicj z owym bojem pod Grodziskiem (K. Pułaski, Z dziejów konfederacji barskiej. Teki Teodora Wessla, podskarbiego w. kor. (1769-1772), w: idem, Szkice i poszukiwania. Seria czwarta, Lwów 1909, s. 12). Gdyby rzeczywiście doszło do walki z Drewiczem, byłby to niebywały sukces, o którym wieść rozbiegłaby się od razu po całym kraju. Mogła Czapskicmu przyjść na pomoc druga część jego własnych sił albo jakiś inny oddział z grupy Drewicza, ale nie byłoby z nim samego słynnego dowódcy.

18 W. Konopczyński (Konfederacja Barska. Przeglqd źródet, „Kwartalnik Historyczny” 1934, z. 3, s. 541; [dalej: Przeglad]) uważa, opierając się na szerszym ujęciu przez Kitowicza poszczególnych walk, że brał on także udział w bitwach pod Radominem 14 września 1769 roku, Kościanem 16 sierpnia 1770 roku, Widawą 23 czerwca 1771 roku i w oblężeniu Poznania 17-30 stycznia 1771 roku. 
3 lutego wie o nim książę August Sułkowski w odległej Rydzynie ${ }^{19}$. Wynikałoby z tego, że Kitowicz znalazł się w grupie Malczewskiego gdzieś w końcu stycznia, już po popisie w Malanowie. Lubiń od Malanowa dzieli spora odległość $103 \mathrm{~km}$ w linii prostej. Zapewne więc gdzieś w połowie stycznia zaciagnął się Kitowicz do jakiegoś oddziałku konfederackiego przebywającego w pobliżu Lubinia, który wkrótce pośpieszył do Malczewskiego. Byłoby jednak prawdopodobne, że przebywanie oddziałów konfederackich w pobliżu Lubinia w końcu grudnia 1768 roku dało ów drugi impuls, który wkrótce skłonił Kitowicza do zaciągnięcia się do ich wojska. Nasuwa się też wpływ chlubnych walk Gogolewskiego, stoczonych w dniach 3-4 stycznia 1769 roku nie tak znowu daleko od Lubinia, ale przeczy temu całkowite o nich milczenie w Pamiętnikach.

Dość sporo w Pamiętnikach mówi autor o działaniach konfederatów w rejonie Pakości-Mątew-Wilczyna 19-21 marca; każdorazowo walczyła tu tylko część sił Malczewskiego. Obszerniejszy jest opis tylko drugiego starcia (21 marca) pod Wilczynem, w którym brali udział konfederaci wybrani z pułków Antoniego Sieroszewskiego, Pawła Skórzewskiego i Wojciecha Grabowskiego (P 222-225), prawdopodobnie więc tylko w nim Kitowicz uczestniczył i służył w jednym z tych oddziałów. 22 marca Malczewski rozpuścił swe siły ${ }^{20}$.

Wiemy, że Kitowicz 23 czerwca 1769 wkroczył do Poznania jako porucznik oddziału Morawskiego. Byłoby więc prawdopodobne, że już wkrótce po rozdzieleniu przez Malczewskiego swych sił 24 marca tegoż roku Kitowicz znalazł się w oddziale oficera-rzeźnika, o którego działaniach sporo pisze. Mamy w Pamiętnikach dość obszerną relację o potyczce pod Lądem, stoczonej około 27 kwietnia 1769 roku.

Jest tu również wzmianka o wybraniu przez Morawskiego kontrybucji w Swarzędzu, według Kitowicza dwa tygodnie po potyczce pod Lądem, według Szczygielskiego - w końcu maja $(P \text { 228-229 })^{21} .23$ czerwca Poznań został zajęty przez por. Ksawerego Jaraczewskiego należącego do grupy Morawskiego. Oddział, który wkroczył do miasta, „prowadzony był bezpośrednio przez por. Jędrzeja Kitowicza zastępcę Jaraczewskiego"22.

9 lipca 1769 roku ks. August Sułkowski pisze do brata Antoniego, że do Rydzyny przybył rotmistrz Kitowicz „z trzydziestu kilku konfederatami bien reglés, disciplinés (...) mówil, że ma powiększać swój oddział" i będzie jutro w Lesznie. Szczygielski podaje, że był on rotmistrzem w pułku Morawskiego ${ }^{23}$.

1 września Jaraczewski, również mający stopień rotmistrza, stał na załodze w Poznaniu, skoro tu wystawił pod tą datą glejt bezpieczeństwa dla szlachcica-protestanta Aleksandra Złotnickiego. Najprawdopodobniej wraz z nim przebywał tu i Kitowicz. Brak bowiem w Pamiętnikach wzmianki o wyprawie Morawskiego pod Toruń i stosunkowo pomyślnej walce tego dowódcy pod Dybowem 22 sierpnia $^{24}$.

\footnotetext{
$19 \mathrm{Sz} K B W$, s. 131, 135.

21) Ibidem, s. 146-148, 150-151.

${ }^{21}$ Ibidem, s. 215-216.

${ }^{22}$ Ibidem, s. 235-237, 312-313.

${ }^{23}$ Przegląd, s. 541; Szkoda, s. 6; Sz KBW, s. 313

${ }^{24} \mathrm{Sz} K B W$, s. 263-264.
} 
Wkrótce jednak Kitowicz zapewne został ściągnięty do swego pułku, mamy bowiem u niego obszerny opis zwycięskiej dla konfederatów bitwy pod Radominem (na wschód od Golubia) 14 września, stoczonej przez pułkowników Morawskiego i Pawła Skórzewskiego (P 234-237), prawdopodobnie więc Kitowicz w niej uczestniczył, jak to przyjmował Konopczyński ${ }^{25}$. Zapewne 29 września brał też udział w aresztowaniu Onufrego Gniewomira Bęklewskiego przez Morawskiego i Skórzewskiego, o czym szeroko się rozpisał (P 323-324). Z drugiej strony nie ma u Kitowicza wiadomości o wyprawie Morawskiego na Pomorze w grudniu, o jego walkach pod Świeciem 8 grudnia, około 31 grudnia pod Toruniem, oraz z Prusakami w okolicy Chojnic około 11 grudnia, a także o bitwie pod Kcynią 29 stycznia 1770 roku, w której uczestniczył pułkownik-rzeźnik ${ }^{26}$.

Między 7 lutego a 20 marca Morawski przebywał w Poznaniu ${ }^{27}$, zapewne wraz z nim był tu $i$ Kitowicz. 19 marca Morawski, opuszczając Poznań, pozostawił go jako dowódcę załogi. 22 marca wobec zbliżania się Rosjan przyszły pamiętnikarz otrzymał rozkaz wycofania się na zachód do Zbąszynia i 23 marca opuścił miasto. Tego dnia stanął „popasem” w Tarnowie. Tam zaskoczył go napad Kozaków. „Uganiał się po wsi z Kozakami blisko dwóch godzin, aż gdy ci zapalili wies”, wycofał, „odstrzelając się Kozakom” przez 3 kilometry do Jankowic. Nieprzyjaciel wycofał się do Tarnowa, a konfederaci przenocowali w Jankowicach. Przybywszy do Zbąszynia, zapewne około 27 marca, Kitowicz pozostawił tu swój oddział „na kępie” na Obrze pod miastem, a sam „udał się szukać Morawskiego”, aby uzyskać od niego rozkazy, „co miał czynić z [tymi] ludźmi pod Zbąszyniem (...), ale Morawski w tym czasie właśnie odprawiwszy potyczkę (...) pod Kościanem [7 IV] (...) sam w kilkadziesiąt koni uszedł" (P 241-243). Tekst ten, niezbyt jasny w końcowym fragmencie, pozwala sądzić, że Kitowicz wobec porażki Morawskiego zrezygnował z poszukiwania go. Tymczasem oddziały na kępie pod Zbąszyniem poddały się Rosjanom (P 243-244) ${ }^{28}$.

Następnie spotykamy się z Kitowiczem w kancelarii regimentarskiej Józefa Zaremby. Janina Kozłowska-Studnicka na podstawie archiwum tego regimentarza pisze, że autor Pamiętników pracował w tym sztabie „od marca 1770 do sierpnia $1771 \mathrm{r} . " 29$. Kłóciłoby się to z informacjami ze wspomnień. Jednak Kozłowska-Studnicka podaje, że „Daty powtarza Kitowicz za oryginałem [pisma], (...) Dzień odbioru (...) przytacza wyjątkowo" ${ }^{30}$. Możliwe więc, że owe zapiski Kitowicza dotyczące marca 1770 roku odnoszą się do jakichś zaległości, które nowy pracownik kancelarii Zaremby uporządkował później.

\footnotetext{
${ }^{25}$ Ibidem, s. 265-267; Przeglad, s. 541.

${ }^{26}$ Sz KBW, s. 362-365, 377-378. W. Konopczyński (Przeglad, s. 541) zauważa: „Można na pewno twicrdzić, żc Kitowicz nic widział ani Dobrej, ani Kcyni, ani Błonia (styczeń-luty 1770), boby inaczcj, bez porównania żywiej i pełniej przedstawił owe ważne chwile". Jeśli chodzi o Dobrą i Błonie, to istotnc jest też, że w bitwach tych nic brał udziału zwicrzchnik Kitowicza - Morawski.

${ }^{27}$ Zob. W. Szczygiclski, Morawski Antoni, w: Polski stownik biograficzny, t. 21, Wrocław 1976, s. 706.

${ }^{28}$ Ibidem.

${ }^{29} \mathrm{~J}$. Kozłowska-Studnicka, Zapiski Jędrzeja Kitowicza na archiwaliach konfederackich 1770-1771, „Pamiçtnik Bibliotcki Kórnickicj" 1955, z. 5, s. 227.

${ }^{30}$ Ibidem, s. 229.
} 
„20 kwietnia 1770 szereg listów otrzymano [w kancelarii Zaremby] w Paruszewicach na Śląsku z opóźnieniem, co sekretarz [-Kitowicz] pozaznaczał"31. Owe Paruszewice to Paruszowice na południowy wschód od Byczyny, a więc tuż przy granicy z Rzecząpospolitą. Kitowicz pisze o nich jako o wsi Parusewie pod Byczyną, gdzie w czasie konfederacji przebywała Józefa, żona Józefa Zaremby (P 252). Dzień 20 kwietnia 1770 roku byłby więc datą pewną sekretarzowania Kitowicza w kancelarii Zaremby.

Zapewne pamiętnikarz brał udział w bitwie swego zwierzchnika pod Kościanem 16 sierpnia, skoro ją obszernie opisał (P 257-262) ${ }^{32}$. Sporo miejsca poświęcił Kitowicz stłumieniu przez Zarembę frondy Malczewskiego 14 lub 15 stycznia 1771 roku i oblężeniu Poznania przez tego regimentarza 17-30 stycznia 1771 (P 263-272), rokowaniom i walce pod Widawą 21-23 czerwca (P 287-293, 741) ${ }^{33}$. Należy przypuszczać, że uczestniczył w tych wydarzeniach.

\section{Opuszczenie przez Kitowicza szeregów konfederackich}

W sierpniu 1771 roku Kitowicz opuścił wojsko konfederackie, aby zostać księdzem. Brak bezpośrednich danych, co go do tego skłoniło. Wokół tej kwestii wyrosło kilka hipotez, których nie sposób tu w pełni omówić. Streszczę więc tylko wyniki moich badań.

Władysław Konopczyński sugerował, nie uzasadniając tego, że Kitowicz w „karierze duchownej” szukał „awansu społecznego”. Badacz ten kładł też nacisk na związki pamiętnikarza z biskupem kujawskim Antonim Ostrowskim. Zapewne pod wpływem przypuszczeń wybitnego historyka powstały koncepcje Kozłowskiej-Studnickiej i Maniewskiej. Odrzucam hipotezę pierwszej autorki, identyfikującej Kitowicza z nieznanym wysłannikiem Zaremby do Ostrowskiego, przebywającym u niego 2-3 sierpnia. Hipoteza autorki, że biskup przekonał Kitowicza, by wobec katastrofalnej sytuacji konfederacji został duchownym, opiera się zapewne na przekonaniu, że Ostrowski rezydował wówczas w Wolborzu. Z kolei Maniewska pisze, iż "bezsprzecznie” w okresie służby Kitowicza u Zaremby nawiązał on „bliższą znajomość” z Ostrowskim „rezydującym w Wolborzu” w pobliżu „Rozprzy i Kisiel” Zarembów. Tymczasem „biskup-zaprzaniec” tak ze względu na swą intensywną działalność polityczną, szczególnie od końca 1770 roku w Radzie Patriotycznej, jak i osłonę bagnetów rosyjskich raczej rezydował w Warszawie. Z pewnością był tu 3 sierpnia 1771, co wynika z listu do Zaremby z tegoż dnia. Oczywiście odległość $250 \mathrm{~km}$ z Warszawy do Kalisza i czas od 3 sierpnia (wyjazd z Warszawy) do 9 sierpnia („obrócenie” Kitowicza „na księdza” przez kustosza kaliskiego Kłossowskiego) sprawiają, że nie mieści się w tym przejazd autora Pamiętnikót do kwatery Zaremby i przekazanie mu „ustnej relacji” od Ostrowskiego, następnie przejazd do Kalisza i owo „obrócenie” "na księdza” przez Kłossowskiego. Notabene sytuacja konfederacji nie była wówczas katastrofalna.

Nie przekonują mnie wywody Maniewskiej, że z listu Kitowicza z seminarium z 24 października 1771 do benedyktyna Ildefonsa Konopki da się wyczytać, iż autor Pamiętników nie czuł

\footnotetext{
31 Ibidem.

32 Przeglad, s. 541; idem, Konfederacja barska, t. 2, Warszawa 1991, s. 449-450 (dalej: K KB).

${ }^{33}$ K KB, t. 2, s. 461-464, 515-516; idem, Kazimierz Pulaski, Kraków 1931, s. 212, 264-266; Przegląd, s. 541.
} 
powołania i wobec tego zamiar zostania księdzem wynikał „z chłodnych obrachunków życiowych”. Z informacji o „odprawieniu jubileuszu” 25-27 września 1751 roku (P 347) wynika, że już w młodości Kitowicz był człowiekiem istotnie pobożnym. Maniewska wysuwa przypuszczenie, że to Ostrowski dał zasiłek na opłacenie seminarium Kitowicza. Przejęła to Matuszewska ( $P$ 27), a za nią inni, zapewne w wyniku przeświadczenia o owej „bezsprzecznie” nawiązanej przez Kitowicza znajomości z Ostrowskim rezydującym w Wolborzu, co jest mylne. Pobyt Kitowicza na wakacjach seminaryjnych w roku 1772 na jego prośbę w Krzcikowicach, dobrach Lipskiego, a nie u Ostrowskiego, wskazywałby, że to raczej ów pierwszy opłacał zasiłek seminaryjny.

Idę za pierwotną koncepcją Romana Pollaka, porzuconą zapewne pod wpływem streszczonych wyżej wywodów Konopczyńskiego. Kitowicz przeżył „głęboki wstrząs psychiczny” (O I, s. XVI), który go skłonił do zostania księdzem. Wstrząs ów - jak sądzę - najprawdopodobniej wiązał się z bratobójczą bitwą pod Widawą 23 czerwca $1771^{34}$.

\section{Poglądy Kitowicza na konfederację barską i jej przywódców}

Mimo że Kitowicz brał udział w konfederacji barskiej, nie przeszkadzało mu to odnosić się krytycznie do niej i do jej przywódców:

Miała też ta konfederacja i proroka (...) niejakiego Marka [Jandołowicza] karmelitę, z pobożności prawdziwej czy obłudnej (sam Bóg wie) wziętego wielce u panów ruskich, który tej konfederacji pomyślny obiecywal skutek (...). Lecz nie sprawdził, bo konfederacja zniszczoną została (P 170).

Członkowie „rozrutnej” Generalności „chęć dobrą ratowania ojczyzny mieli, choć serca bić się za nią nie mieli. (...) Tymczasem sami w Preszowie (...) bankietowali, w karty tysiące czerwonych złotych (...) przegrywali”. Eudzili się, że uzyskają pomoc zagraniczną (P 174-175). Generalność ogłaszała bezkrólewie, „a król królem, pod opieką Moskwy bezpiecznie na tronie siedział i śmiał się z głupstwa takowego Generalności, która go z tronu spychała piórem, a sama nie śmiała i krokiem wstapić z zagranicy do kraju” (P 211). Ten obraz „tragikomicznego widowiska” (wedle określenia Przemysławy Matuszewskiej) ${ }^{35}$ wzięty jako całość jest karykaturą, choć składa się z wielu trafnych spostrzeżeń.

Odróżnia Kitowicz Generalność od „konfederacji bijącej się w kraju”, ale i o niej kąśliwie się wyraża: „albo właściwiej pisząc, bitej ciągle” ( $P$ 174).

Kazimierz Pułaski „w potyczkach zapominał o wszystkim i sam $(. .$.$) w największe niebezpie-$ czeństwo się narażał. Dlatego też często przegrywał”. Zwyciężał jedynie, gdy towarzyszył mu Antoni Schütz (Szyc), będący znacznie wybitniejszym dowódcą (P 189-190). Jest to oczywiście w dużej mierze błędne. Niewątpliwie Kazimierz Pułaski poniósł wiele porażek, ale mimo to był najwybitniejszym wodzem konfederacji barskiej. Zresztą sam Kitowicz pisze o obronie Jasnej

${ }^{34}$ Zob. M WJK; W. Konopczyński, Szkoda, s. 6; K KB, t. 2, s. 516; J. Kozłowska-Studnicka, op. cit., s. 234-235, 239; P, s. 27 (P. Matuszewska, Wstęp); D. Maniewska, op. cit., s. 349-350, 352-354, 357-358; S. Lubomirski, Pamiętniki, Lwów 1925, s. 174-175.

${ }^{35}$ P, s. 10 (P. Matuszewska, Wstęp); zob. P. Matuszewska, Proza Jędrzeja Kitowicza, Wroclaw 1965, s. 126. 
Góry (P 273-277), jednym z największych sukcesów Pułaskiego, w której Schütz nie brał udziału. Dowódca ów zresztą rzadko współdziałał z marszałkiem łomżyńskim i bynajmniej wtedy razem nie odnosili znaczących sukcesów ${ }^{36}$.

Niewątpliwie Kitowicz najlepiej poinformowany był o konfederacji barskiej w Wielkopolsce, o ruchu poza tym terenem wiedział nie za dużo i niejednokrotnie była to wiedza niezgodna z prawdą. Według niego Ignacy Malczewski, marszałek wielkopolski był „płochego i porywczego geniuszu (...) a przy tych talentach, robocie przedsięwziętej przeciwnych, serca zajęczego" (P 193). "Nikogo do ażardu życia nie przymuszał, bo sam najpierwszy przed nieprzyjacielem uciekał” (P 202). Kitowicz podnosi, że jego działania „wytępiły jednak niemało Moskalów” (P 206). Odznaczał się okrucieństwem: mianował sędzią Ignacego Chlebowskiego, ten „żadnego czucia sprawiedliwości i miłosierdzia nie mający”, „dziada, Żyda”, włóczęgę „bez wszelkiej indagacji wieszać kazał” (P 197). Według Konopczyńskiego Malczewski „okazał pewien talent organizacyjny”, „przy zupełnym braku uzdolnień wojskowych” - co w tym wypadku oznacza jedynie brak talentów dowódczych. Uważa, że Chlebowski poza podejrzanymi o szpiegostwo, wieszanymi „za lada podejrzeniem”, tracił również rabusiów. Wacław Szczygielski ceni wyżej Malczewskiego, sądzi, że był obdarzony „dużym zmysłem organizacyjnym, energią, wytrwałością i umiejętnością współżycia z ludźmi”. Przyznaje, że marszałek „nie miał jednak uzdolnień strategicznych [dowódczych - W. M.] i na dowódcę większego oddziału się nie nadawał”. Dalej Szczygielski podnosi umiejętności Malczewskiego ubezpieczania się i wykorzystania terenu, poza tym jednak jego opinia o dowodzeniu Malczewskiego jest ujemna. Brak ogólnego ujęcia sprawy ewentualnego tchórzostwa marszałka. Jeśli chodzi o walkę pod Częstochową 11 lutego 1769 roku, Szczygielski uważa za Kitowiczem, że Malczewski pierwszy uszedł z placu boju. Podnosi jednak, że (w bitwie pod Zawadami 12 lutego 1770) marszałek „wykazywał wiele odwagi i męstwa”37.

Kitowicz zamieścił liczne pochwały dotyczące pierwszego okresu działalności słynnego partyzanta, a swego zwierzchnika Antoniego Morawskiego, zanim został on pułkownikiem. Natomiast o drugim okresie jego działalności autor Pamiętników wyraża się niemal wyłącznie ujemnie albo też ukazuje mocno pobieżnie jego ówczesne sukcesy. Historycy mają o tym późniejszym okresie lepsze zdanie.

Według Kitowicza Morawski w początkach swych działań „najeżdżał sprawnie moskiewskie stacje” (posterunki? - P 222). Wiosną 1769 roku niepokoił skutecznie załogę poznańską. Parokrotnie zaskoczony przez Rosjan w Gnieźnie, Słupcy, pod Wierzbnem zdołał się przebić (P 226-229). Sądzi jednak Kitowicz, że w stoczonej przez Morawskiego zwycięskiej potyczce pod Radominem 14 września, ,jako też i w innych” stoczonych po zostaniu pułkownikiem „nic znacznego nie dokazał. Ochraniał się aż nadto”. Stawał w potyczkach „na ustroniu”. Nie chciał stracić pieniędzy zdobytych poprzednio na Kozakach (P 235-236). Niezbyt to wiarygodne, żeby dowódca nie miał wpływu na walkę swego oddziału; dowódca pułku musiał w większym stopniu niż dowódca

\footnotetext{
${ }^{36}$ Zob. W. Kriegseisen, Schütz (Szyc) Antoni, w: Polski stownik biograficzny, t. 36, Wrocław 1995, s. 57-58; W. Majcwski, Próba charakterystyki dziejów wojskou ych konfederacji barskiej, „Myśl Wojskowa” 1959, nr 3, s. 75-77.

${ }^{37} \mathrm{~K} K B$, t. 1, s. 194-195; Sz KBW, s. 137, 200-202, 387.
} 
choragwi dowodzić z tyłu. O pobycie Morawskiego w Poznaniu od 7 lutego do 20 marca 1770 Kitowicz pisze, że ten siedział bezczynny. $Z$ tekstu wynika jednak, iż pułkownik prowadził ćwiczenia. Można mieć wątpliwości, czy należy oceniać je tak ujemnie, jak to robi autor Pamiętników. (P 240-241). Wacław Szczygielski podaje, że Morawski „Umacniał fortyfikacje miasta”38. Kitowicz informuje o pijaństwie pułkownika, które wystapiło silnie w czasie owego pobytu w Poznaniu, a później przyczyniło się do jego dostania się do niewoli 12 kwietnia 1770 roku (P 241, 245-246). Tylko mimochodem wspomina Kitowicz ( $P$ 268) o alarmowaniu Poznania przez Morawskiego w nocy z 19 na 20 stycznia 1771 r., chociaż działania te trwały 14 godzin, a pułkownik opanował Św. Marcina i Rybaki. Podobnie został ujęty udział Morawskiego w bitwie pod Widawą 23 czerwca 1771 roku (P 291), mimo że ten według Szczygielskiego „W znacznym stopniu przyczynił się do wygranej” ${ }^{39}$. Zdaniem Kitowicza do dostania się pułkownika-rzeźnika do niewoli w Piotrkowie 25 czerwca przyczyniło się to, że „Odpadła go dawna odwaga”. Z opisu przebiegu wydarzeń nie bardzo to wynika. Nie dowodzi braku męstwa ukrycie się (P 293-294), skoro Morawski był sam wobec licznego przeciwnika. Informuje przecież dalej Kitowicz o zorganizowaniu przez pułkownika w czasie jego niewoli ucieczki 90 jeńców w Ledóchowie koło Krzemieńca. Dopadnięty przez pogoń bronił się „do upadłej” bagnetem, a to przecież wymagało dużej dozy męstwa, dopiero ranny dostał się do niewoli (P 294-295). W sumie, mimo że Morawski jest niejednokrotnie ukazany w korzystnym świetle, mamy u Kitowicza sporo ujęć krytycznych. Niejednokrotnie bywa to krytycyzm uzasadniony, w paru wypadkach zabrakło dodatniej oceny działań Morawskiego.

Matuszewska widzi w Kitowiczu „przyjaciela domu” Zarembów (P 27), również i Janina Kozłowska-Studnicka tak go charakteryzuje ${ }^{40}$. Sam Kitowicz określa Józefa Zarembę jako „dobrego kawalera” (P 250). Mimo to nieraz osądza go surowo, znacznie ostrzej niż Morawskiego.

Autor Pamiętnika uważa, że bitwę pod Kościanem 16 sierpnia 1770 roku regimentarz wielkopolski wygrał dzięki przypadkowi (P 264), co wydaje się dość prawdopodobne. Dalej jednak Kitowicz pisze, że Zaremba nie zaatakował samego Kościana, bo obawiał się, że bẹdzie odpowiedzialny za ewentualny rabunek kosztowności Antoniego Sułkowskiego i jego siostry (P 201). Władysław Konopczyński sądzi, że właściwą przyczyną był brak zgody wśród dowódców konfederackich ${ }^{41}$.

Według Kitowicza jeszcze przed oblężeniem Jasnej Góry (31 XII 1770-15 I 1771) Kazimierz Pułaski zwrócił się do Zaremby z prośbą o pomoc. Ten odmówił, stwierdziwszy, że musi najpierw stłumić bunt Malczewskiego. Po aresztowaniu tego ostatniego regimentarz wielkopolski poszedł pod Poznań, aby dzięki jego oblężeniu sprawić, żeby Rosjanie odeszli spod Częstochowy. Zdaniem Kitowicza działania te jednak nie skłoniłyby Rosjan do odwrotu spod Jasnej Góry. Oblężenie Poznania (19-31 I 1771) prowadził Zaremba opieszale i zbyt szybko się stamtąd wycofał. Jak twierdzi autor Pamiętników, samo energiczne ostrzeliwanie miasta znużyłoby nieliczną załogę

38 W. Szczygielski, Morawski Antoni, op. cit., s. 706.

${ }^{39}$ Ibidem, s. 706-707.

40 Zob. J. Kozłowska-Studnicka, op. cit., s. 234.

${ }_{41} \mathrm{~K} K B$, t. 2, s. 450. 
i zmusiłoby Rosjan do poddania Poznania (P 265-272). Pułaski nie wzywał nikogo pod Jasną Górę przed oblężeniem, a nawet wyprawił część swych sił z Częstochowy, bo twierdza jasnogórska była zbyt mała, by pomieścić większą liczbę obrońców. Gdy jednak Jasna Góra została oblężona, istotne było, żeby napady na większe garnizony rosyjskie skłoniły przeciwnika do odwrotu. I rzeczywiście spowodował to atak na Kraków Józefa Miączyńskiego. Według Konopczyńskiego, aby wyruszyć pod Poznań, Zaremba musiał najpierw stłumić bunt Malczewskiego. Zaraz po jego aresztowaniu regimentarz wielkopolski około 10 stycznia wysłał kilkaset jazdy pod Częstochowę dla nękania oddziałów Drewicza. Badacz wskazuje na warunki niesprzyjające szturmowi Poznania. Chłopi niosący drabiny pierzchli po pierwszych strzałach kartaczowych, szturm od strony Warty utrudniała odwilz, tylko część podkomendnych dowódców Zaremby była za podjęciem szturmu. Konopczyński nie uważa jednak, by były to przeszkody uniemożliwiające w ogóle atak, na pewno jednak warunki przemawiały w jakiejś mierze przeciw decyzji szturmu ${ }^{42}$.

Kitowicz sugeruje, że doszło do zawarcia jakiegoś układu między Rosjanami a Zarembą: od czasu oblężenia Poznania „uważaliśmy, że nigdy na niego ani Renn [Karl Rönne], ani [Iwan] Drewicz nie natarł”, a po śmierci eks-regimentarza wielkopolskiego znalazła się w jego papierach „libertacja pułkownika Renna [zwalniająca jego dobra] od wszelkich furażów” (P 280).

Informacje te Konopczyński uznał za tak dalece niewiarygodne, że pominął te kwestie milczeniem. Można tu dodać, że Zaremba co prawda rzadko w ogóle staczał walki, jednak nawet w końcowej fazie konfederacji 23 marca 1772 roku bił się zawzięcie pod Piotrkowem ${ }^{43}$ i właściwie posądzenie go o zdradę jest nieuzasadnione.

Znajdujemy u Kitowicza i dodatnie opinie o Zarembie. Pamiętnikarz podnosi, że w walce o Piotrków 9 grudnia 1769 roku położył Rosjan „trupem przeszło dwieście”, a gdy przybyły im posiłki, „uszedł w dobrej sprawie”, następnie rozdzielił swe oddziały „na kilka traktów, aby nieprzyjaciel nie wiedział, gdzie go ma gonić" (P 251).

Opisuje Kitowicz zwycięstwo Zaremby nad Ksawerym Branickim pod Widawą 23 czerwca 1771 roku (P 290-292), walkę pod Piotrkowem 23 marca 1772, w której „do walniejszej sprawy nie doszło”, ale Zaremba „w dobrej sprawie cofnął się”(P 283). W rzeczywistości była to jednak "uparta bitwa" z próbą opanowania Piotrkowa ${ }^{44}$.

Pisze Kitowicz, że Zaremba przekonał swych oficerów, aby ogłoszonej przez Generalność „detronizacji (...) nie publikować”, bo przeciw konfederacji wystąpią teraz i wojska królewskie. Zaremba „dobrze zrobił” ( $P$ 281). „Był [to] jednak dobry żołnierz”. Chociaż „szczerze nie bił Moskalów, to przynajmniej ochronę wojska swego cnotą nazwać można” (P 313). W sumie jednak owe sądy ujemne przeważają.

Zapewne surowe oceny Kitowicza wywolała gorycz spowodowana ostateczną klęską konfederacji. Od starożytnej Grecji bowiem poprzez czasy Wielkiej Rewolucji Francuskiej czy naszego powstania listopadowego opinia publiczna zwykła przypisywać klęski straszliwej, niezrozumiałej nieudolności dowódców, ich złej woli, kierowaniu się materialnymi korzyściami czy nawet

\footnotetext{
42 Ibidem, s. 462-463.

${ }^{43}$ Ibidem, s. 645.

44 Ibidem, s. 643.
} 
zdradzie. Nie inaczej musiało być i po upadku konfederacji. I tym ogólnym nastrojom, jak widać, uległ Kitowicz.

Rozdziałki poświęcone Barowi powstały po latach, w roku 1788, a później były przeredagowane w ostatnich kilku latach XVIII wieku i paru pierwszych latach następnego stulecia. Natomiast teksty dotyczące roku 1794 pisane były na bieżąco. Widać tu wyraźnie pochwały wodzów polskich w okresie ich sukcesów. Tak Antoni Madaliński, wszczynając powstanie w 1794 roku, chciał „pokazać się potrzebnym ojczyźnie żołnierzem” (P 582). Obronę Warszawy przez Kościuszkę określa Kitowicz jako „wspaniałe dzieło”. „Warszawa żadnymi murami nie opasana na płaszczyźnie z tej strony [skąd przeciwnik ją oblegał] położona broniła się przez całe 9 niedziel obiema wojskom nieprzyjacielskim”. „Wszystkie te pomyślności były dziełem jednego Kościuszki, on się wszystkim zatrudniał, on w każdej akcji sam byl przytomny (...) raził mocno nieprzyjaciela z małą swoich stratą" (P 598-599).

Obraz ten po klęskach od razu się zmienia. „Taki był koniec i skutek tej nieszczęśliwej wojny zapalonej przez Madalińskiego, a roznieconej przez Kościuszkę bez dobrego fundamentu" (P 620). Kościuszko dla narodu „stal się narzędziem wszelakiego jego nieszczęścia” (P 621). Jeśli jednak Naczelnikowi Kitowicz nie odmawia przynajmniej dobrej woli, to według niego Madaliński kierował się tylko interesem własnym. „Madaliński nie był zdrajcą (...), ale nie był prawdziwym ojczyzny miłośnikiem, bo jej w złym razie nie ratował" (P 630). To ostatnie zdanie jest całkowicie niezrozumiałe i nie objaśnia go Kitowicz. „Chodziło mu najwięcej o swoją egzystencję, dlatego porwał się do broni”. Dalej mamy niejasną informację, że „stracił swoją substancję” w roku 1793 i początkach 1794, utrzymując liczny dwór i żyjąc rozrzutnie. Potem następuje nieoczekiwany wniosek: „Taka tedy pobudka Madalińskiego do porwania się na Prusaków nie może być nacechowaną miłością ojczyzny, ale miłością własną" ( $P$ 630-631). Trzeba to połączyć z poprzednimi informacjami u Kitowicza, że brygada Madalińskiego miała zostać zwinięta (P 582, 587). Wynikałoby $z$ tego, że Madaliński rozpoczął powstanie, aby zachować stanowisko brygadiera, co oczywiście jest nonsensem. Wystarczy tu fakt, że brygadę planowano jedynie zredukować, a więc Madaliński miał zachować swoje stanowisko.

Według Kitowicza po zdobyciu Pragi Madaliński, nie dbając o ratowanie „fortuny publicznej, zatrudnił się jedynie około swojej” i zabrał dla siebie kasę pruską skonfiskowaną w Bydgoszczy (P 617, zob. s. 608).

To przejście Kitowicza od euforii w okresie zwycięstw do złorzeczeń i oskarżeń po klęsce skłania do przypuszczenia, że podobnie musiało być z poglądami autora Pamiętników na konfederację barską, że to gorycz klęski skłaniała do potępiania ponad miarę, choć oczywiście rzeczywistość barska, oceniana obiektywnie, wielokrotnie skłania do ujemnych ocen.

Być może na owe oskarżenia w jakiejś mierze składało się też przeświadczenie, że historyk powinien oceniać krytycznie ludzi i wydarzenia, a ponieważ często zamiast wiarygodnych źródeł miał Kitowicz do dyspozycji złośliwe plotki, dawał im wiarę. To niewątpliwie wymaga jeszcze dalszych badań. 